\title{
Aktivitas Imunomodulator Polyscias obtusa Terhadap Sistem Imunitas Pada Bone Marrow Broiler Setelah Pemberian Salmonella typhimurium
}

\author{
Erin Kurnianingtyas ${ }^{1}$, Muhammad Sasmito Djati ${ }^{1}$, dan Muhaimin Rifa' $i^{1}$ \\ ${ }^{1}$ Laboratorium Fisiologi Hewan, Jurusan Biologi, Fakultas Matematika dan Ilmu Pengetahuan Alam \\ Universitas Brawijaya, Malang
}

\begin{abstract}
ABSTRAK
Antibiotik banyak dimasukkan dalam pakan ternak untuk menanggulangi penyakit ternak, namun pemberian antibiotik dalam waktu lama dapat menyebabkan resistensi dan juga residu bagi manusia. Polyscias obtusa memiliki senyawa saponin, tanin, dan flavonoid yang diduga sebagai imunomodulator dalam sistem imunitas tubuh. Tujuan penelitian ini untuk mengetahui pengaruh daun $P$. obtusa sebagai imunomodulator terhadap imunitas anak ayam broiler. Metode penelitian diantaranya uji konfirmasi bakteri, persiapan kultur bakteri dan daun $P$. obtusa, pembuatan pakan ransum dosis $1(0.08 \%)$, dosis $2(0.16 \%)$ dan dosis $3(0.26 \%)$ dari daun $P$. obtusa, infeksi S. typhimurium $500 \mu$ l secara oral di hari ke-14, pembedahan pertama pada hari ke-24, pembedahan terakhir pada hari ke-34, sel limfosit diisolasi pada organ bone marrow dan diinkubasi dengan antibodi rat-anti-CD4 ${ }^{+} \mathrm{PE}$, rat-anti-CD8 ${ }^{+}$FITC, dan rat-anti-CD45 ${ }^{+}$PerCP masingmasing sebanyak $50 \mu \mathrm{l}$ kemudian dilakukan running flowcytometri. Hasil menunjukkan bahwa secara keseluruhan perlakuan yang paling menunjukkan dalam peningkatan sel limfosit adalah perlakuan yang diberi dosis daun $P$. obtusa, yaitu perlakuan pakan ransum dosis $0,08 \%$, perlakuan pakan ransum dosis $0,16 \%$, dan perlakuan pakan ransum dosis $0,26 \%$. Jumlah relatif $\mathrm{CD}^{+}$mengalami peningkatan dengan hasil yang berbeda nyata. Sehingga dapat dibuktikan bahwa daun $P$. obtusa mampu berperan sebagai imunomodulator dalam sistem imunitas.
\end{abstract}

Kata kunci : Ayam broiler, Polyscias obtusa, Salmonella typhimurium, sel

ABSTRACT

Antibiotics are included in animal feed to recover the diseases, but giving antibiotics for a long term can cause resistance and also residues to humans. Polyscias obtusa have saponins, tannins, and flavonoids compounds which are assumed as imunomodulator in the body's immunity system. The purpose of this research was to determine the influence of $P$. obtusa leaf as imunomodulator on chicks broiler immunity. Research methods are including bacteria confirm test, bacterial culture preparation and $P$. obtusa leaves, the making of diet with $0.08 \%, 0.16 \%$ and $0.26 \%$ dose from $P$. obtusa leaves. Total of $500 \mu \mathrm{l}$ S. typhimurium infected orally on day $14^{\text {th }}$, the first surgery on day $24^{\text {th }}$ and the last surgery on day $34^{\text {th }}$. Lymphocyte cells are isolated on the bone marrow and incubated with rat anti-CD4-PE, rat antiCD8-FITC, and rat-anti-CD45 PerCP antibodies respectively $50 \mu \mathrm{l}$ and then runned in flowcytometri. Result show an increase in lymphocyte cells in the treatment given a dose of $P$. obtusa leaves, feed rations treatment dosage of $0.08 \%$, $0,16 \%$, and $0.26 \%$. Increase in CD4 relatives number are significantly different. So, it can be proven that $P$. obtusa leaves are able to act as the immune system imunomodulator.

Keywords : Broiler, cell, Polyscias obtusa, Salmonella typhimurium

\section{PENDAHULUAN}

Kendala dalam sektor peternakan diantaranya penurunan jumlah ternak karena serangan penyakit. Salah satu penyakit yang umum menyerang ayam peternakan adalah serangan penyakit dari bakteri Salmonella sp. Untuk menanggulangi permasalahan tersebut para

\footnotetext{
* Alamat Korespondensi:

Muhammad SasmitoDjati

Email : msdjati@ub.ac.id

Address : Department of Biology, Faculty of Mathematics and Natural Sciences, Brawijya University,

Jl. Veteran, Malang 65154
}

peternak dan perusahaan peternakan unggas melakukan pemberian antibiotik.

Antibiotik telah diketahui berguna untuk memberantas penyakit dan juga dapat berfungsi sebagai growth promotor pada ayam. Namun pemberian antibiotik dalam waktu lama dapat menyebabkan munculnya permasalahan baru berupa resistensi bakteri patogen terhadap antibiotik yang diberikan. Salmonella typhimurium akan bersifat resisten terhadap antibiotik seperti ampisilin, kotrimoksasol dan tetrasiklin [1]. Antibiotik juga dapat menimbulkan residu yang berbahaya bagi manusia akibat mengkonsumsi produk unggas. Berbeda dengan 
antibiotik, penggunaan obat herbal memiliki keuntungan tidak menyebabkan residu pada hasil produksi ternak.

Daun Polyscias obtusa yang dapat meningkatkan ketahanan tubuh pada ayam. Daun pada tanaman ini memiliki kandungan asam oleanic saponin. Selain senyawa saponin, pada tanaman ini juga ditemukan senyawa flavonoid dan tanin. Saponin merupakan senyawa aktif yang bersifat seperti sabun, serta memiliki kemampuan membentuk busa dan menghemolisis sel darah merah [2]. Hasil uji secara in vitro dari flavonoid golongan flavones dan flavonols telah menunjukkan adanya respon imun [3]. Efek terhadap respon imun non spesifik berupa peningkatan fagositosis dan kemotaksis makrofag, kemotaksis neutrofil, sitotoksisitas sel NK serta aktivitas hemolisis komplemen $[4,5]$.

Pemberian antigen $S$. typhimurium pada anak ayam umur 1 - 2 minggu hanya menimbulkan respon antibodi yang lemah. Kondisi ini mungkin disebabkan oleh sifat hiporesponsif sel-sel pada sistem imunitas yang belum berfungsi secara mature [6], atau diseminasi jaringan limfoid masih sangat muda dan fungsi pembentukan antibodi belum sempurna, sehingga antibodi yang terbentuk pada anak ayam rendah [6]. Berdasarkan uraian di atas bahwa perlu diadakan penelitian lebih lanjut untuk mengetahui aktifitas imunomodulator daun Polyscias obtusa terhadap sistem imunitas terutama pada bone marrow broiler setelah infeksi Salmonella typhimurium.

\section{METODE PENELITIAN \\ Waktu dan Tempat}

Penelitian ini dilaksanakan pada bulan Maret hingga Juli 2012 di Laboratorium Mikrobiologi dan Laboratorium Fisiologi Hewan, Jurusan Biologi, Fakultas MIPA, serta Laboratorium peternakan Sumber Sekar DAU, Fakultas Peternakan, Universitas Brawijaya, Malang.

\section{Alat dan Bahan}

Alat yang digunakan dalam penelitian ini yaitu cawan petri, jarum oose, tabung reaksi, gelas obyek, pipet, inkubator, tissue, vorteks, erlenmeyer, mikropipet, bola hisap, kandang, tempat makan, tempat minum, dan lampu. Sedangkan untuk bahan yang digunakan yaitu media NA, NB, XLD, KIA, LIA, cat gram A, B, C dan $D$, larutan $\mathrm{H}_{2} \mathrm{O}_{2}$, aquades, formalin, batu kapur, pakan pabrik BR1, pakan ransum (DL Metionin, tepung ikan, jagung kuning, precampuran, bungkil kopra, bungkil kedelai dan garam) dan air mineral.

\section{Uji Konfirmasi \\ Uji media XLD}

Isolat murni yang akan diuji, diambil dengan ose dan dilakukan streak plate pada media XLD kemudian diinkubasi pada suhu $37^{\circ} \mathrm{C}$ selama 24 jam. Uji akan menunjukkan hasil positif bila pada daerah streak tersebut akan membentuk koloni berwarna hitam.

\section{Uji Katalase}

Isolat bakteri diletakkan pada gelas obyek kemudian ditetesi dengan hidrogen peroksida $\left(\mathrm{H}_{2} \mathrm{O}_{2}\right) \quad 3 \%$ sebanyak satu tetes. Uji positif ditunjukkan ketika terdapat gelembung pada saat penetesan $\mathrm{H} 2 \mathrm{O} 2$, akan tetapi jika tidak terdapat gelembung maka uji ini dianggap negatif [8].

\section{Uji Patogenitas}

Isolat bakteri murni dilakukan streak plate pada media blood agar. Isolat bakteri diinkubasi pada suhu 37으 selama 24-48 jam. Uji akan menunjukkan hasil positif apabila media berubah warna menjadi bening secara menyeluruh di sekitar koloni.

\section{Uji Pewarnaan Cat Gram}

Isolat pada gelas obyek difiksasi di atas api. Apusan ditetesi dengan larutan Gram A (Hucker's crystal violet), cat gram B (Lugol'siodine), cat gram C (alkohol), cat gram D (safranin) masingmasing selama satu menit. Apusan bakteri dicuci kembali pada air mengalir dan dikeringanginkan. Kemudian apusan bakteri diamati dengan menggunakan mikroskop. Hasil menunjukkan bakteri bersifat gram negatif karena hasil akhir berwarna merah.

\section{Uji Media KIA dan LIA}

Isolat bakteri yang telah diremajakan diambil dengan enten, selanjutnya enten ditusukkan dan ditarik pada media KIA dan LIA. Selanjutnya diinkubasi pada suhu $37^{\circ} \mathrm{C}$ selama 24-48 jam. Pada uji media KIA dan LIA, jika media berubah warna menjadi hitam maka bakteri tersebut memproduksi $\mathrm{H}_{2} \mathrm{~S}$.

\section{Kurva Standar}

Isolat bakteri ditumbuhkan pada media Nutrien Broth dengan kosentrasi pengenceran berbeda. Kemudian diukur absorbansinya dengan spektrofotometer pada panjang gelombang 
$600 \mathrm{~nm}$ dan dihitung jumlah selnya dengan haemocytometer.

\section{Kurva Pertumbuhan}

Kultur bakteri diambil 1 ose yang ditumbuhkan pada media Nutrien Broth $10 \mathrm{ml}$ dan diinkubasi suhu $37^{\circ} \mathrm{C}$ selama 24 jam. Kemudian diambil $6 \mathrm{ml}$ kultur dan dicampur media NB $54 \mathrm{ml}$. Kemudian dilakukan sampling setiap 1 jam, dengan mengambil $4 \mathrm{ml}$ dan ditambah $500 \mu \mathrm{l}$ formalin. Kemudian diukur absorbansinya dengan spektrofotometer pada panjang gelombang $600 \mathrm{~nm}$ dan dihitung jumlah selnya dengan haemocytometer. Tabel 1 menunjukkan perbandingan antara media steril dan kultur.

Tabel 1. Perbandingan stok bakteri Salmonella typhimurium dengan media steril

\begin{tabular}{ccc}
\hline Perbandingan & Stok kultur $(\mathbf{m l})$ & Media Steril $(\mathbf{m l})$ \\
\hline $8: 0$ & 0 & 4 \\
$7: 1$ & 0,5 & 3,5 \\
$6: 2$ & 1 & 3 \\
$5: 3$ & 1,5 & 2,5 \\
$4: 4$ & 2 & 2 \\
$3: 5$ & 2,5 & 1,5 \\
$2: 6$ & 3 & 1 \\
$1: 7$ & 3,5 & 0,5 \\
$0: 8$ & 4 & 0 \\
\hline
\end{tabular}

\section{Pembuatan Pakan Konversi}

Daun $P$. obtusa kemudian dicuci dan dikering anginkan. Kemudian daun dihaluskan menggunakan blender kering dan hasilnya disebut simplisia. Selanjutnya simplisia ditimbang dan ditambahkan pada pakan buatan ayam sesuai perlakuan yaitu perlakuan dengan dosis 1 berjumlah $0,08 \%$, untuk dosis 2 berjumlah $0,16 \%$, sedangkan untuk dosis 3 berjumlah 0,26\% Polyscias obtusa yang diberikan.

\section{Pemberian Salmonella typhimurium secara oral}

Bakteri Salmonella typhimurium dalam Nutrient Broth disentrifuse dengan kecepatan $10.000 \mathrm{rpm}$ selama 10 menit suhu $25^{\circ} \mathrm{C}$. Pelet yang diperoleh diresuspensi dengan larutan garam fisiologis $\mathrm{NaCl} 0,9 \%$ yang diambil sebanyak $500 \mu \mathrm{l}$ dan diberikan kepada ayam secara oral menggunakan pipet tetes.

\section{Isolasi Sel Limfosit}

Tulang femur ayam yang sudah dibersihkan, dipotong bagian kedua ujungnya dan sel diflush dengan PBS menggunakan jarum $19 \mathrm{G}$.
Selanjutnya sel-sel yang diperoleh difilter menggunakan wire dan dimasukkan kedalam tabung propilen $15 \mathrm{ml}$. Ditambahkan PBS sampai $12 \mathrm{ml}$. Disentrifugasi dengan kecepatan 2500 rpm, pada suhu $4^{0} \mathrm{C}$, selama 5 menit hingga didapat pelet dilanjutkan dengan sentrifugasi kembali hingga pelet terakhir yang merupakan sel limfosit.

\section{Analisis Flowcytometri}

Sel-sel yang diisolasi dari bone marrow diinkubasi dengan rat-anti-CD45 ${ }^{+}$PerCP, rat-anti$\mathrm{CD} 8^{+} \mathrm{FITC}$, dan rat-anti $\mathrm{CD} 4^{+} \mathrm{PE}$ conjugated. Sampel yang telah diinkubasi dengan antibodi ditambah $1 \mathrm{ml}$ PBS dan ditempatkan pada kuvet flowcytometer. Selanjutnya dipilih acquire dan flowcytometer akan menghitung jumlah sel total serta jumlah sel yang terdeteksi oleh label antibodi. Hasil yang diperoleh diolah dengan program $B D$ cellquest Pro ${ }^{T M}$.

\section{Analisis Statistika}

Analisis data dilakukan dengan menggunakan metode RAL-Faktorial pada program SPSS 16 for Windows. Apabila diperoleh hasil yang signifikan maka dilakukan uji lanjut Tukey.

\section{HASIL DAN PEMBAHASAN Profil Sel $\mathrm{CD}^{+}, \mathrm{CD}^{+}$dan $\mathrm{B220}^{+}$}

Jumlah relatif $\mathrm{CD}^{+}$dan $\mathrm{CD} 8^{+}$dengan analisa flowcytometry masing-masing perlakuan pada fase starter menunjukan perbedaan yang signifikan. Jumlah relatif $\mathrm{CD}^{+}$tertinggi dihasilkan dari kelompok perlakuan pakan pabrik, yaitu sebesar $4,47 \%$, sedangkan untuk jumlah relatif $\mathrm{CD}^{+}$tertinggi dihasilkan dari kelompok perlakuan P.obtusa dosis 0,08\% sebesar 10,91\% (Gambar 1).

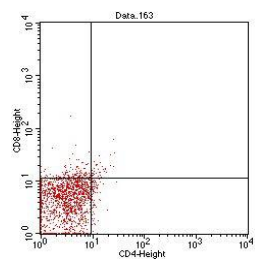

(a)

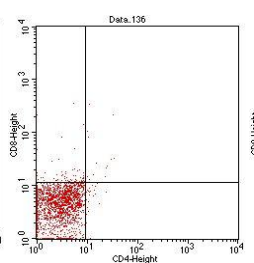

(b)

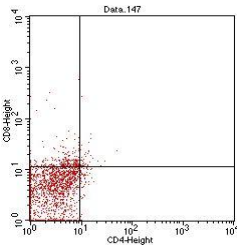

(c)

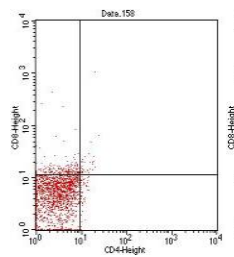

(d)

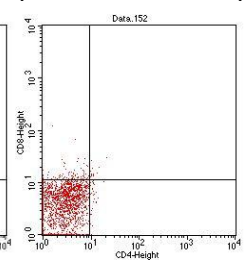

(e)
Gambar 1. Profil $\mathrm{CD} 4^{+}$dan $\mathrm{CD} 8^{+}$fase starter pada perlakuan (a) pakan pabrik, (b) pakan pabrik + 
infeksi S. typhimurium, (c) P. obtusa $0,08 \%$, (d) P.obtusa 0,16\%, (e) P. obtusa $0,26 \%$

Jumlah relatif $\mathrm{CD}^{+}$dan $\mathrm{CD} 8^{+}$dengan analisa flowcytometry masing-masing perlakuan pada fase finisher menunjukkan perbedaan yang signifikan. Jumlah relatif $\mathrm{CD}^{+}$tertinggi dihasilkan dari kelompok perlakuan $P$. obtusa dosis $0,08 \%$, yaitu sebesar $3,52 \%$, sedangkan untuk jumlah relatif $\mathrm{CD}^{+}$tertinggi dihasilkan dari kelompok perlakuan $P$. obtusa dosis $0,08 \%$ sebesar $3,98 \%$ (Gambar 2). Hal ini bisa terjadi karena masih adanya suatu rangsangan antigen yang menyebabkan sel limfosit terus berproliferasi. Secara umum jumlah leukosit yang meningkat merupakan pertanda adanya infeksi [9].

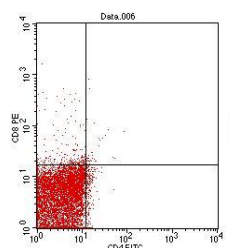

(a)

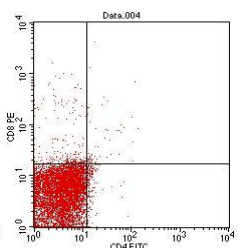

(b)

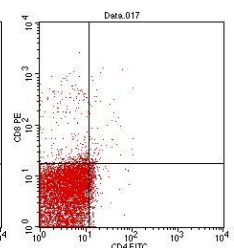

(c)

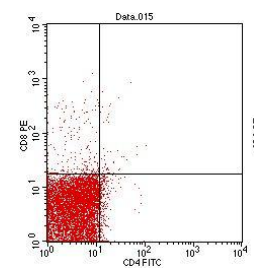

(d)

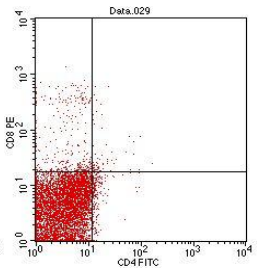

(e)
Gambar 2. Profil $\mathrm{CD}^{+}$dan $\mathrm{CD}^{+}$fase finisher pada perlakuan (a) pakan pabrik, (b) pakan pabrik + infeksi S. typhimurium, (c) P. obtusa 0,08\%, (d) P. obtusa $0,16 \%$, (e) P. obtusa $0,26 \%$

Jumlah relatif $\mathrm{B}_{220^{+}}$dengan analisa flowcytometry masing-masing perlakuan pada fase starter menunjukkan perbedaan yang tidak signifikan. Jumlah relatif $\mathrm{B}_{2} 2 \mathrm{O}^{+}$tertinggi dihasilkan dari kelompok perlakuan $P$. obtusa dosis $0,16 \%$, yaitu sebesar $2,60 \%$, sedangkan untuk jumlah relatif $\mathrm{B}_{2} 20^{+}$terendah dihasilkan dari kelompok perlakuan pakan pabrik sebesar 1,20\% (Gambar 3).

Jumlah relatif $\mathrm{B}^{2} 20^{+}$dengan analisa flowcytometry masing-masing perlakuan pada fase finisher menunjukkan perbedaan yang tidak signifikan. Jumlah relatif ${\mathrm{B} 220^{+}}^{+}$tertinggi dihasilkan dari kelompok perlakuan P.obtusa dosis $0,16 \%$, yaitu sebesar 9,34\%, sedangkan untuk jumlah relatif $\mathrm{B}^{2} 20^{+}$terendah dihasilkan dari kelompok perlakuan pakan pabrik dengan infeksi S. typhimutium sebesar 5,82\% (Gambar 4).

Hasil jumlah relatif sel limfosit menunjukkan adanya perbedaan yang signifikan. Ini diduga karena adanya senyawa pada tanaman $P$. obtusa yang dapat mengatur aktifitas sel limfosit untuk berproliferasi. Senyawa dari tanaman tersebut adakalanya akan meningkatkan jumlah sel limfosit, tetapi juga bisa sebagai imunosupressan. Senyawa antibakteri seperti saponin apabila berada dalam tubuh ternak terlalu lama dapat menurunkan daya tahan tubuh [10]. Jumlah relatif $\mathrm{CD}^{+}, \mathrm{CD}^{+}$dan $\mathrm{B}^{2} 20^{+}$secara keseluruhan memiliki jumlah tertinggi pada kelompok perlakuan yang diberi $P$. obtusa dosis $0,08 \%$ dan $0,16 \%$. Hal ini mengindikasikan kemungkinan dosis tersebut merupakan dosis optimum yang dapat berfungsi sebagai imunostimulator.

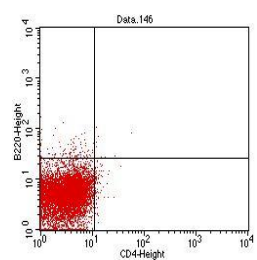

(a)

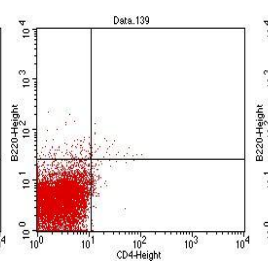

(b)

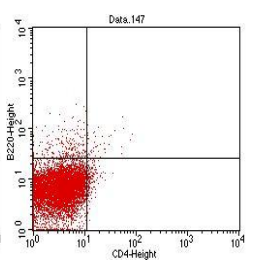

(c)

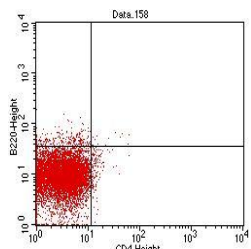

(d)

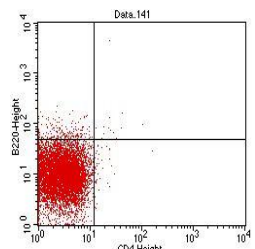

(e)
Gambar 3. Profil $\mathrm{B}^{2} 20^{+}$fase starter pada perlakuan (a) pakan pabrik, (b) pakan pabrik + infeksi S. typhimurium, (c) $P$. obtusa $0,08 \%$, (d) $P$. obtusa $0,16 \%$, (e) P. obtusa $0,26 \%$

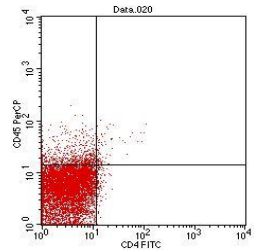

(a)

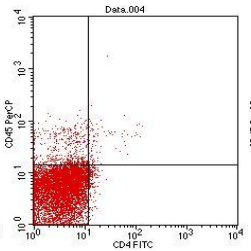

(b)

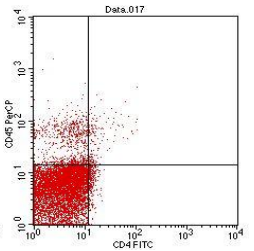

(c)

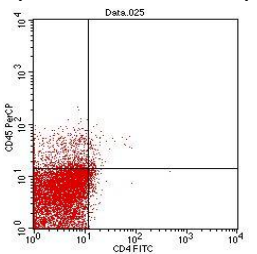

(d)

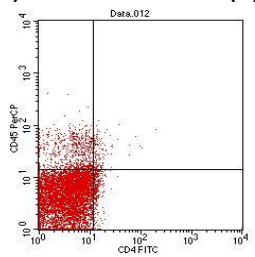

(e)
Gambar 4. Profil $B 220^{+}$fase finisher pada perlakuan (a) pakan pabrik, (b) pakan pabrik + infeksi S. typhimurium, (c) $P$. obtusa $0,08 \%$, (d) $P$. obtusa $0,16 \%$, (e) P. obtusa $0,26 \%$ 


\section{Sel $\mathrm{CD}^{+}, \mathrm{CD}^{+}$dan $\mathrm{B220}^{+}$Pada Organ Bone Marrow Ayam Broiler}

Hasil pada fase starter menunjukkan bahwa jumlah relatif $\mathrm{CD}^{+}$paling tinggi yaitu pada perlakuan kontrol negatif sebesar 3,4\%. Kelompok perlakuan pakan ransum dosis $0,26 \%$ memiliki nilai paling rendah yakni sebesar $1,32 \%$. Jumlah relatif $C D 4^{+}$yang paling rendah pada fase finisher yaitu pada perlakuan kontrol positif sebesar $1,32 \%$ dan untuk jumlah relatif sel $\mathrm{CD}^{+}$ yang paling tinggi yaitu pada perlakuan pakan ransum dosis $0,08 \%$ sebesar $2,72 \%$ (Gambar 5 ).

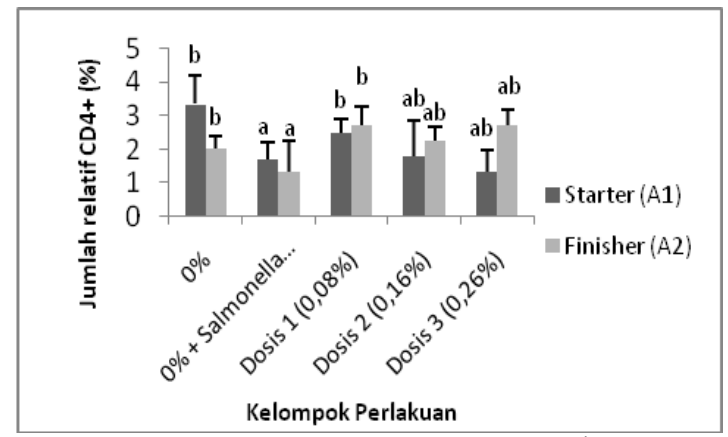

Gambar 5. Rata-rata Jumlah Sel T CD4 ${ }^{+}(\%)$ fase Starter dan Finisher $(p<0.05)$

Hasil pada fase starter menunjukkan bahwa jumlah relatif $\mathrm{CD}^{+}$tertinggi pada perlakuan kontrol negatif sebesar $6,47 \%$ sedangkan untuk jumlah relatif $\mathrm{CD} 8^{+}$paling rendah pada perlakuan kontrol positif sebesar 3,09\%. Jumlah relatif $C D 8^{+}$ terendah pada fase finisher perlakuan kontrol positif dengan nilai sebesar $1,46 \%$ dan untuk jumlah relatif $\mathrm{CD}^{+}$yang paling tinggi pada perlakuan pakan ransum dosis $0,26 \%$ sebesar 2,92\% (Gambar 6).

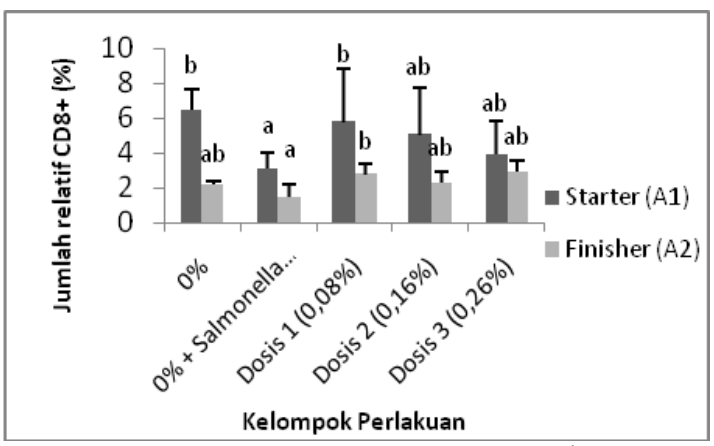

Gambar 6. Rata-rata Jumlah Sel T $\mathrm{CD}^{+}(\%)$ fase Starter dan Finisher $(p<0.05)$

Hasil pada fase starter menunjukkan bahwa jumlah relatif $\mathrm{B}_{2} 2 \mathrm{O}^{+}$yang paling rendah terdapat pada perlakuan kontrol positif yaitu sebesar $0,47 \%$ dan untuk jumlah relatif tertinggi pada perlakuan pakan ransum dosis $0,16 \%$ sebesar $1,89 \%$. Jumlah relatif $\mathrm{B} 220^{+}$fase finisher yang tertinggi pada perlakuan pakan ransum dosis $0,16 \%$ yakni sebesar $5,51 \%$ dan untuk jumlah

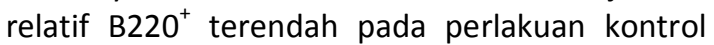
positif sebesar 3,80\% (Gambar 7).

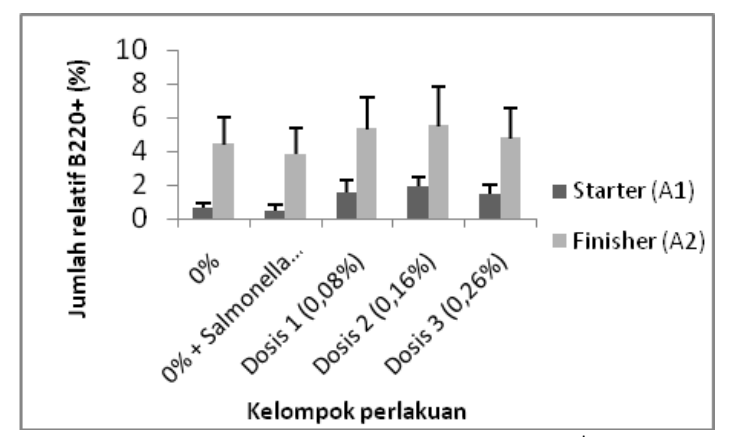

Gambar 7. Rata-rata Jumlah Sel $B 220^{+}(\%)$ fase Starter dan Finisher $(p<0.05)$

Infeksi bakteri Salmonella typhimurium dapat menginduksi aktivasi sel $\mathrm{T} \mathrm{CD}^{+}$dan sel $\mathrm{T} \mathrm{CD}^{+}$. Fungsi Sel $\mathrm{T} \mathrm{CD}^{+}$membantu aktivasi dan deferensiasi sel $B$ selain itu juga membantu pembentukan sel $\mathrm{T}^{\mathrm{CD}} 8^{+}$spesifik Salmonella. Pembentukan sel $\mathrm{T}$ juga diindikasikan dengan adanya produksi IFN- $\gamma$ [11-17]. Produksi IFN- $\gamma$ spesifik Salmonella typhimurium dari sel T $\mathrm{CD} 4^{+}$ secara signifikan lebih besar daripada sel T CD8 ${ }^{+}$. Jika berupa IL-2 dan IFN $\gamma$, yang berkembang adalah Th1 dan akan menekan Th2. Sebaliknya jika IL-4 yang dikeluarkan, maka Th2 yang akan berkembang [18].

Saponin memproduksi cytokines seperti interleukin dan interferons yang berperan dalam efek imunostimulan. Interleukin dan interferons akan bereaksi dengan antigen (benda-benda asing) yang masuk ke dalam tubuh [19]. Saponin dalam jumlah normal berperan sebagai immunostimulator, sedangkan dalam jumlah yang melebihi batas normal saponin akan berperan sebagai immunosupresor (zat yang menekan/menurunkan sistem imun) [20]. Batas toleransi penggunaan saponin adalah $3,7 \mathrm{~g} / \mathrm{kg}$ pakan [21]. Batas toleransi tanin dalam ransum ayam broiler sebesar 2,6g/kg pakan [23].

Kenaikan sel limfosit $\mathrm{T}$ dan sel limfosit B selain diindikasikan dari suatu senyawa yang dapat merangsang proliferasi sel limfosit tetapi juga dikarenakan adanya ekspos terhadap antigen sehingga merangsang sel limfosit untuk berganda lebih cepat. 


\section{KESIMPULAN}

Pemberian dosis daun Polyscias obtusa yang berbeda menunjukkan profil jumlah relatif $\mathrm{CD}^{+}, \mathrm{CD}^{+}$dan $\mathrm{B}^{2} 20^{+}$antara semua perlakuan memiliki perbedaan yang signifikan berdasarkan analisis flowcytometry dan menunjukkan adanya peningkatan. Hubungan starter dan finisher menunjukkan hasil yang tidak terdapat perbedaan yang signifikan pada jumlah relatif $\mathrm{CD}^{+}, \mathrm{CD}^{+}$, dan $\mathrm{B} 220^{+}$.

\section{DAFTAR PUSTAKA}

[1] Tabbu, C.R. 2000. Penyakit Ayam dan Penanggulangannya. Vol 1. Kanisius. Yogyakarta.

[2] Robinson, T. 1995. Kandungan Organik Tumbuhan Tinggi . Edisi ke-6. Terjemahan: K. Padmawinata. ITB-Press, Bandung.

[3] Hollman, P.C.H, M.G.L. Hertog and M.B. Katan, 1996. Analysis and Health Effects of Flavonoids. Food Chemistry, 57 (1) : 43-46.

[4] Munasir Z. 2002. Manfaat pemberian ekstrak Phyllanthus niruri sebagai imunostimulator pada penyakit infeksi anak. http://www.tnial.mil.id/cakrawala.php3.

[5] Rifa'i, M., Y. Kawamoto, I. Nakashima, H. Suzuki. 2004. Essential roles of $\mathrm{CD} 8^{+} \mathrm{CD} 122^{+}$ regulatory $T$ cells in the maintenance of $T$ cell homeostasis. The Journal of experimental medicine, 200 (9): 1123-1134.

[6] Jeurissen, S.H.M., E.M. Janse, G. Koch And G.F. Deboer.1989. Post natal development of mucosa-associated lymphoid tissue in chickens. Cell Tissue Res., 258: 119-124.

[7] Corkish, J.D., R.H. Davies, C. Wray and R.A. Nicholas. 1994. Observation on broiler breeder flock naturally infected with Salmonella enteritidis phage type 4. Vet. Rec. 134: 591 - 594.

[8] Fardiaz, S. 1993. Analisis Mikrobiologi Pangan. Jakarta : PT.Raja Grafindo Persada.

[9] Frandson, R. D. 1992. Anatomi dan Fisiologi Ternak. Edisi 4. Terjemahan. Gadjah Mada University Press, Yogyakarta.

[10] Cheeke, P. R. 1989. Toxicants of Plants Origin, Volume IV. Phenolics. CRC Press.

[11] Endharti, A.T., M. Rifa'I, Z. Shi, Y. Fukuoka, Nakahara, Y. Kawamoto, K. Takeda, K. Isobe, H. Suzuki. 2005. Cutting edge: CD8+CD122+ regulatory $T$ cells produce IL-10 to suppress IFN-gamma production and proliferation of CD8+ T cells. Journal of immunology, 175 (11): 7093-7097.

[12] Lee, Y.H., Y. Ishida, M. Rifa'i, Z. Shi, K. Isobe, H. Suzuki. 2008. Essential role of
$\mathrm{CD} 8^{+} \mathrm{CD} 122^{+}$regulatory $\mathrm{T}$ cells in the recovery from experimental autoimmune encephalomyelitis. The Journal of Immunology, 180 (2): 825-832.

[13] Rifa'i, M., Z. Shi, S.Y. Zhang, Y.H. Lee, H. Shiku, K. Isobe, H. Suzuki. 2008. $\mathrm{CD}^{+} \mathrm{CD} 12^{+}$ regulatory $T$ cells recognize activated $T$ cells via conventional MHC class I- $\alpha \beta T C R$ interaction and become IL-10-producing active regulatory cells. International immunology, 20 (7): 937-947.

[14] Shi, Z., Y. Okuno, M. Rifa'i, A.T. Endharti, K. Akane, K. Isobe, H. Suzuki. 2009. Human $\mathrm{CD}^{+} \mathrm{CXCR}^{+}{ }^{+}$cells have the same function as murine $\quad \mathrm{CD} 8^{+} \mathrm{CD} 122^{+}$Treg. European journal of immunology, 39 (8): 2106-2119.

[15] Shi, Z., M. Rifa'i, Y.H. Lee, H. Shiku, K. Isobe, H. Suzuki. 2008. Importance of CD80/CD86$\mathrm{CD} 28$ interactions in the recognition of target cells by $\mathrm{CD}^{+} \mathrm{CD} 122^{+}$regulatory $\mathrm{T}$ cells. Immunology, 124 (1): 121-128.

[16] Rifai'i, M. 2010. Andrographolide ameliorate rheumatoid arthritis by promoting the development of regulatory T cells. Journal of Tropical Life Science, 1 (1): 5-8.

[17] Lee, Y.H., M. Rifa'i. 2011. CD $4^{+} \mathrm{CD} 25^{+}$FOXP3 $^{+}$ Regulatory $T$ Cells In Allogeneic Hematopoietic Cell Transplantation. Journal of Tropical Life Science, 1 (2): 69-75.

[18] Mastroeni P, Ménager N. 2003. Development of acquired immunity to Salmonella. J. Med. Microbiol. 52:453-59.

[19] Tizard, I. 1988. Pengantar Imunologi Veteriner. Edisi Ke 2. Terjemahan Masduki Partodirejo. Airlangga University Press, Surabaya.

[20] Francis, G., Zohar K., Harinder, P.S.M., dan Klaus B. 2002. The biological action of saponins in animal sistems. British Journal of Nutrition 88: 587-605.

[21] Food and Agriculture Organization. 2005. Endogenous and Exogenous Feed Toxins. http://www.fao.org/docrep/article/Agrippa /659_en_10. htm3TopOfPage2005. Diakses tanggal 20 Februari 2013.

[22] Kumar, V, A. V. Elangovan, and A. B. Mandal. 2005. Utilization of reconstitued high-tanin sorghum in the diets of broiler chicken. J. Anim. Sci. 18 (4): 538-544. 